\title{
The changes of the purple coneflower's (Echinacea purpurea L.) herb and radix drug yield under different fertilization conditions
}

\author{
Judit Éva Lelesz - József Csajbók \\ University of Debrecen, Faculty of Agricultural and Food Sciences and Environmental Management, Institute of Crop Sciences, Debrecen \\ lelesz.judit@agr.unideb.hu
}

\begin{abstract}
SUMMARY
In this research, the purple coneflower's (Echinacea purpurea L.) nutrient requirement was examined under different fertilization conditions in a small plot experiment. We measured the medicinal plant's raw and dry herb and root drug mass and drying loss under different fertilization settings and meteorological factors.

From the drug's raw and dry mass perspective, based on the results, in our opinion, the control setting exceeded all nutrient settings' results in 2016. In 2017 and 2018, the $N_{75} P_{100} K_{150}$ nutrient setting has the biggest herb yield. As for the root yield, it was also the $N_{75} P_{100} K_{150}$ setting which produced the biggest yield.

The Pearson's correlation test was performed to investigate the connection between the quantity of the raw, the dried herbs, the different nutrient settings and meteorological factors.
\end{abstract}

Keywords: herb, nutrient requirement, purple coneflower, herb, root

\section{INTRODUCTION}

There are many uncertainties in herbs' specific nutrient requirements (Valkovszki, 2011). The Echinacea purpurea L. is a herbaceous plant, which is endemic in North-America. Nowadays, three species of the Echinacea genus are important in medicine, The E. purpurea, the E. angustifolia and the E. pallida. (Bernáth, 2000).

The dried flowering herb (Echinaceae purpureae herba, Echinaceae angustifoliae herba, Echinaceae pallidae herba) and roots (Echinaceae purpureae radix, Echinaceae angustifoliae radix, Echinacea pallidae radix) of all three species are marked as drugs. (Pluhár et al., 2012).

The stable active ingredients of commercially available formulations of Echinacea are polysaccharides and alkylamides. They enhance the defensive power of the human body, while they also have antiviral, antibacterial, anti-inflammatory and wound healing effect (Babulka, 1998).

Many uses are known in the USA. Its root and flower are used for snake milling, the purified plant is used for wounds and inflammations and the root is used for gonorrhea (Meuninck, 2016). Similarly, other herbs (ginseng, aloe vera, and dandelion) the Echinacea has a blood-pressure-lowering and cholesterol-lowering effect (Goodier, 2016).

Cultivation takes $2-3$, or 4 years. It could be reproducible with sowing in place, division, or seedling. The most popular propagation method is seedling cultivation. In the case of restoration, the initial slow growth of the plants has a significant risk of discoloration. The sharing of the plants is a cumbersome and less effective method in need of expert skills (Bernáth, 2000).

In India, the root is used as an antivenin. In Italy, the dried leaves' hot water extract is used to treat inflammations (Ross, 2001). A concentrated echinacea herb and root extract is as effective as the conventional antiviral medicine against flu (Raus et al., 2015). A complex was isolated from the herb, which is marked for cough supressing (Capek et al., 2015). The Echinacea complex has significant bronchodilatory and anti-inflammatory effects (Sutovska et al., 2015).

This plant is demandint to nutrients and lime. It is best developed in medium-sized, well-water-rich, humus and nitrogen-rich chernozem soil. The wellnutrient, humus-rich sandy soils are also suitable for the production of roots (Bernáth, 2000). Purple coneflower' $s$ survival rate in salt tolerance is the highest among the Echinacea species (Sabra et al., 2012).

According to Praszna et al.'s (1992) research findings, in the case of autumn planting, no significant yield is expected in the following year. The seedlings, which leaving in may, were outstanding in the following year in growth and yield.

\section{MATERIALS AND METHODS}

The experiment took place in the experiment site of the University of Debrecen, Agricultural Research Institutes and Farming, DTTI Presentation Garden. The experimental place's soil is chernozem. It is characterized by the accumulation of humus and easy tillage. The forecrops were potato and sunflower. The used plot size was $8 \mathrm{~m}^{2}$, arranged in 4 replications in randomized blocks, with 6 different fertilizer treatment levels.

In 2014, the regular nutrient dosages were applied. First on 5 March $201448 \mathrm{~kg} \mathrm{ha}^{-1}$ nitrogen, $66 \mathrm{~kg} \mathrm{ha}^{-1}$ phosphorous $\left(\mathrm{P}_{2} \mathrm{O}_{5}\right)$ and $88 \mathrm{~kg} \mathrm{ha}^{-1}$ potassium $\left(\mathrm{K}_{2} \mathrm{O}\right)$ were applied. The second nutrient supply took place on 28 October 2014 in the form of $38 \mathrm{~kg} \mathrm{ha}^{-1}$ nitrogen, 31 $\mathrm{kg} \mathrm{ha} \mathrm{k}^{-1}$ phosphorous $\left(\mathrm{P}_{2} \mathrm{O}_{5}\right)$, and $37 \mathrm{~kg} \mathrm{ha}^{-1}$ potassium $\left(\mathrm{K}_{2} \mathrm{O}\right)$. Nutrient supply affected yield. The fertilizer dosages of the experiment were spread manually. 
The fertilizer doses were:

$\begin{array}{ll}> & \mathrm{N}_{0} \mathrm{P}_{0} \mathrm{~K}_{0} \text { (Control) } \\ > & \mathrm{N}_{15} \mathrm{P}_{20} \mathrm{~K}_{30} \\ > & \mathrm{N}_{30} \mathrm{P}_{40} \mathrm{~K}_{60} \\ > & \mathrm{N}_{45} \mathrm{P}_{60} \mathrm{~K}_{90} \\ > & \mathrm{N}_{60} \mathrm{P}_{80} \mathrm{~K}_{120} \\ > & \mathrm{N}_{75} \mathrm{P}_{100} \mathrm{~K}_{150} \quad \mathrm{~N} \%, \mathrm{P}_{2} \mathrm{O}_{5} \%, \mathrm{~K}_{2} \mathrm{O} \%\end{array}$

In 2015, the rainfall on the experimental area from $1^{\text {st }}$ January to $30^{\text {th }}$ September was considerably less $(286.2 \mathrm{~mm})$ than the 30 -year average $(445.8 \mathrm{~mm})$. From January until the end of September, the average temperature of each month was higher than the 30-year average. In 2016, the rainfall from $1^{\text {st }}$ January to $31^{\text {th }}$ August was considerably more $(574.9 \mathrm{~mm})$ than the 30 year average. From the $1^{\text {st }}$ January to $31^{\text {th }}$ August in 2016, the measured monthly mean temperature was higher than the 30-year average. In 2017 the precipitation remained below the 30 -year average. This was particularly perceptible in May when it was more than $30 \mathrm{~mm}$ "missing" compared to the average precipitation. However, the monthly measured mean temperature exceeded the 30-year average. In 2018, the average temperature exceeded the average of thirty years in several months. This year was extremely dry, more than $90 \mathrm{~mm}$ was missing from the annual rainfall by $20^{\text {th }}$ September.

Sowing was $30^{\text {th }}$ March in 2015 into seedling trays. The first plants were emerged $7^{\text {th }}$ April. The planting were between $18^{\text {th }}$ and $21^{\text {st }}$ May. The harvest of the herb was $4^{\text {th }}$ July in $201610^{\text {th }}$ July in 2017 and $26^{\text {th }}$ June in 2018.

The harvest of the coneflower's herb were in full bloom, with 25-30 cm long stalk, with secateurs manually. We harvested one line from each plot. In the case of the roots, we harvested 20 plant per plot in three replicates. Before the measurement the roots were purified with running water. In all cases, the drug was weighed in raw state than and a sample was taken for drying and for the drying loss calculation. We dried the herb under prenumbra for three weeks in 2016. In 2017 because of the rainy weather, we used drying cabinet on $40{ }^{\circ} \mathrm{C}$ for 72 hours and the roots for 48 hours. We measured the raw and the dry mass of the herb and the three years old roots, we picked up $7^{\text {th }}$ and $8^{\text {th }}$ November in 2017.

During processing of the data, Pearson's correlation test were applied by using MS Excel 2010 and IBM SPSS 22.0 programmes. We investigated the relationships between the raw and dry drug yields, the different nutrient settings and the meteorological factors (temperature, precipitation, air humidity, soil temperature, global radiation). Global radiation is the amount of the direct and the scattered radiation from the sun. We used the 8-week-long preharvest periods meteorological data. In the case of temperature, air humidity and soil temperature, we used the average of the obtained data, in the case of precipitation and global radiation, the amount was used.

\section{RESULTS AND DISCUSSION}

Figure 1 shows the raw and dry herb yield changes depending on the nutrient supply in 2016. The control setting exceeded all nutrient settings' results. Of the different nutrient settings, we measured the highest herb yield in the $\mathrm{N}_{15} \mathrm{P}_{20} \mathrm{~K}_{30}$ and the lowest in the $\mathrm{N}_{60} \mathrm{P}_{80} \mathrm{~K}_{120}$.

Figure 1: Quantity of the coneflower raw and dry herb yield depending on the nutrient supply in 2016 (Debrecen, 2016)

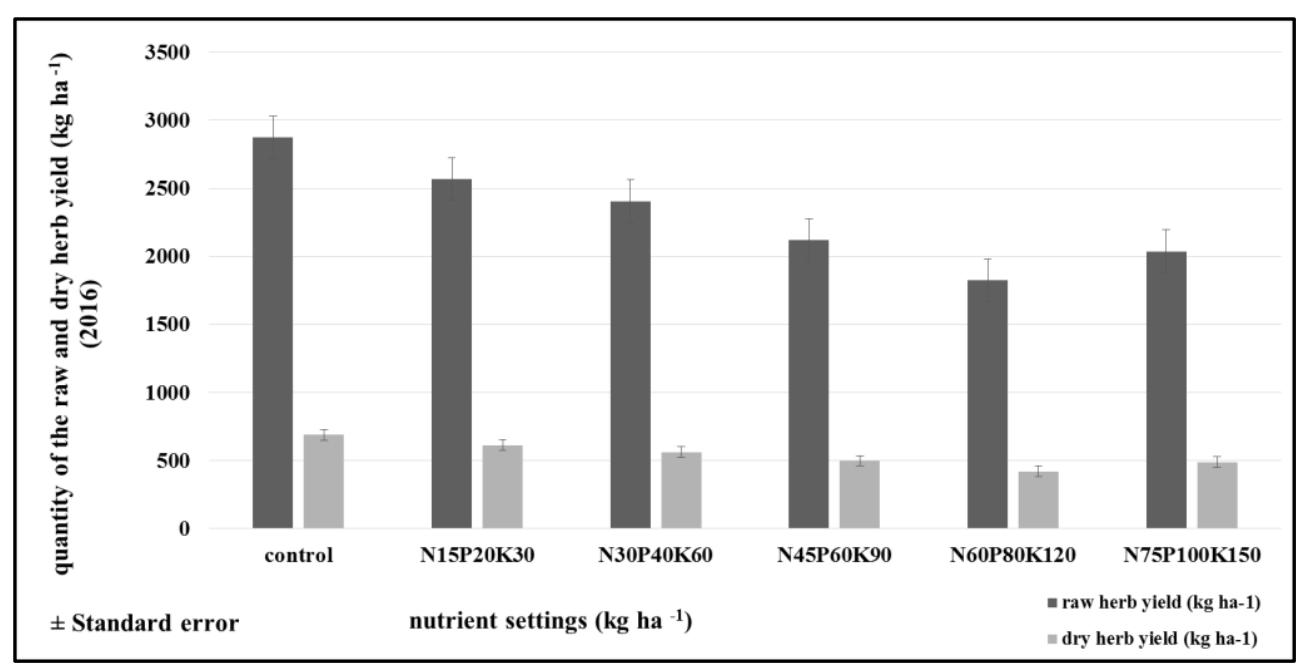

Figure 2 shows the herb yield changes in 2017 . The control setting reached the minimum in contrary to the year 2016. We measured the highest herb yield in the $\mathrm{N}_{75} \mathrm{P}_{100} \mathrm{~K}_{150}$ plots.

Figure 3 shows the herb yield fluctuations in 2018. The $\mathrm{N}_{15} \mathrm{P}_{20} \mathrm{~K}_{30}$ setting reached the minimum. With minimal fluctuations we observed an increasing in the yield with the increasing of the increasing of the nutrient settings. We measured the highest herb yield in the $\mathrm{N}_{75} \mathrm{P}_{100} \mathrm{~K}_{150}$ plots again.

Figure 4 shows the roots' yield data. There is a maximum in $\mathrm{N}_{75} \mathrm{P}_{100} \mathrm{~K}_{150}$, and a minimum in $\mathrm{N}_{30} \mathrm{P}_{40} \mathrm{~K}_{60}$ settings. The control group's yield has exceeded that of $\mathrm{N}_{15} \mathrm{P}_{20} \mathrm{~K}_{30}$ and the $\mathrm{N}_{30} \mathrm{P}_{40} \mathrm{~K}_{60}$ groups. 
Figure 2: Quantity of the coneflower raw and dry herb yield depending on the nutrient supply in 2017 (Debrecen, 2017)

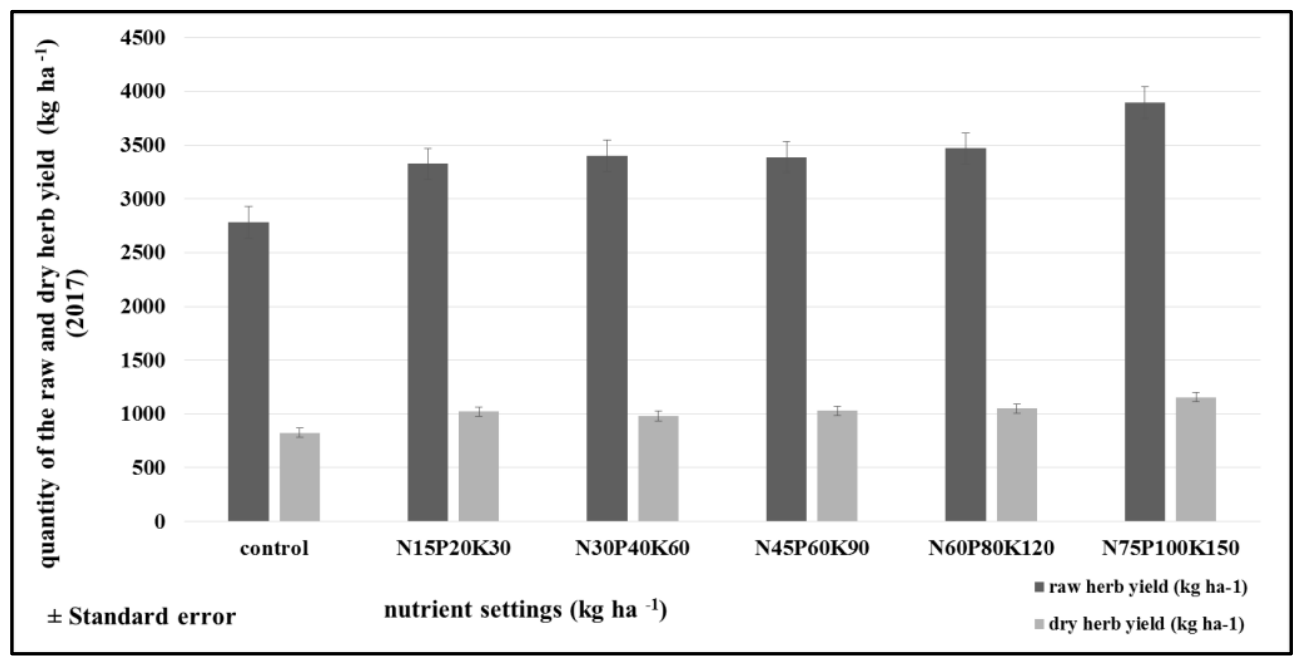

Figure 3: Quantity of the coneflower's raw and dry herb yield depending on the nutrient supply in 2018 (Debrecen, 2018)

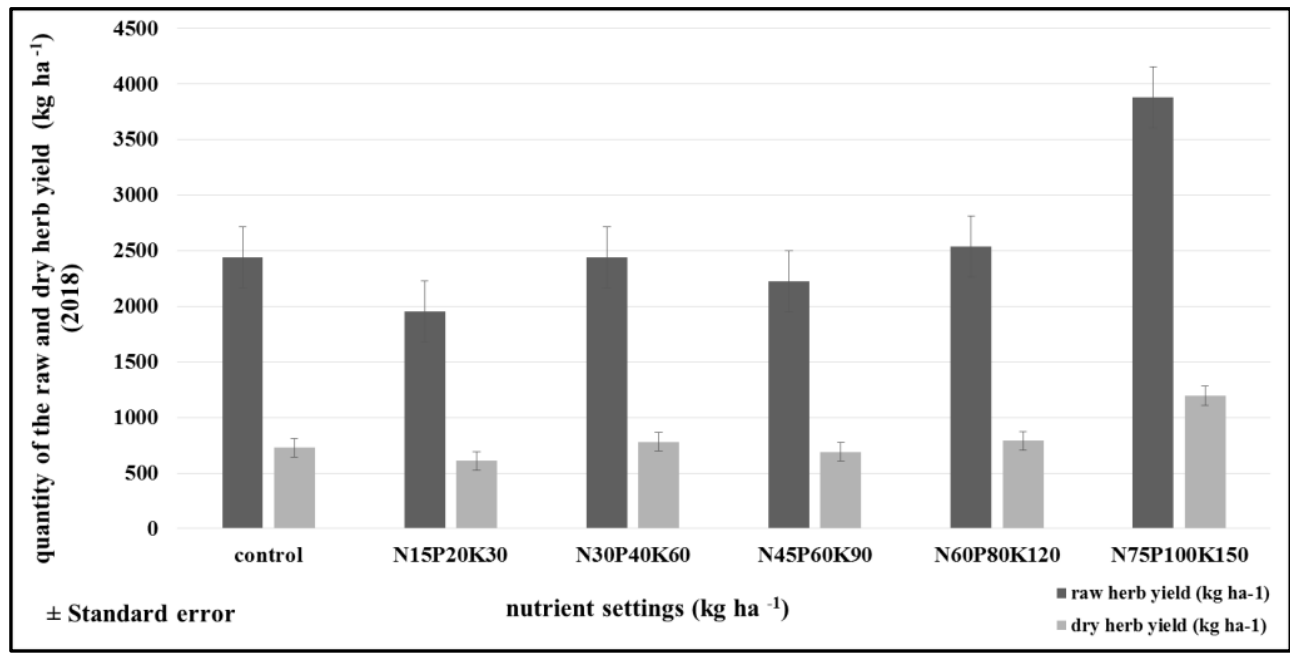

Figure 4: Quantity of the coneflower's raw and dry root yield depending on the nutrient supply in 2018 (Debrecen, 2018)

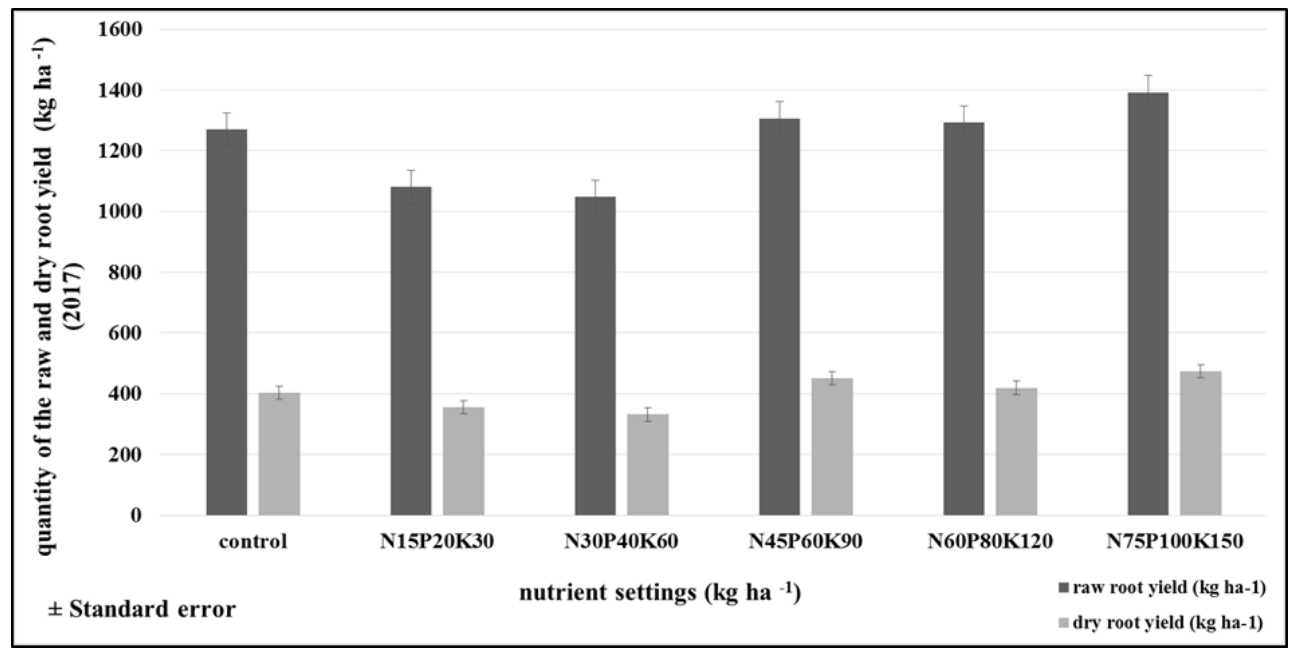


With the Pearson's correlation test we examined the correlations between the drug yields and the nutrient settings and the meteorological factors. Using the three investigated years raw yield data we did not find statistically evaluable relationship between the raw herb yield and the nutrient settings $(r=0.131)$. The raw and the dry herb yield has a very strong relationship at $1 \%$ significance level $(r=0.950)$.

The temperature had not statistically evaluable effect on the raw yield and the precipitation is just the sixth week has negative medium effect at $1 \%$ significance level. We measured the air humidity and the raw yield negative medium relationship $(\mathrm{P}=0.01)$. The soil temperature has a medium effect on the raw yield from the fourth week preharvest $(\mathrm{P}=0.05)$. Between the raw yield and the global radiation we measured a medium relationship at $1 \%$ significance level (Table 1).

Table 1

The relationship between the raw herb yield of the coneflower and the eight-week long preharvest period's meteorological characteristics (Debrecen, 2018)

\begin{tabular}{|c|c|c|c|c|c|c|c|c|}
\hline Raw yield & 1. week & 2. week & 3. week & 4. week & 5. week & 6. week & 7. week & 8. week \\
\hline Temperature & 0.044 & 0.046 & 0.115 & 0.146 & 0.156 & 0,167 & 0,203 & 0,224 \\
\hline Precipitation & 0.088 & 0.106 & -0.187 & -0.104 & -0.156 & $\begin{array}{c}-0.390 \\
* *\end{array}$ & $\begin{array}{c}-0.334 \\
* *\end{array}$ & $\begin{array}{c}-0.317 \\
* *\end{array}$ \\
\hline Air humidity & $\begin{array}{c}-0.443 \\
* *\end{array}$ & $\begin{array}{c}-0.454 \\
* *\end{array}$ & $\begin{array}{c}-0.454 \\
* *\end{array}$ & $\begin{array}{c}-0.450 \\
* *\end{array}$ & $\begin{array}{c}-0.454 \\
* *\end{array}$ & $\begin{array}{c}-0.434 \\
* *\end{array}$ & $\begin{array}{l}-0.454 \\
* *\end{array}$ & $\begin{array}{c}-0.431 \\
* *\end{array}$ \\
\hline Soil temperature & -0.082 & 0.049 & 0.217 & $\begin{array}{c}0.346 \\
* *\end{array}$ & $\begin{array}{c}0.453 \\
* *\end{array}$ & $\begin{array}{l}0.451 \\
* *\end{array}$ & $\begin{array}{c}0.361 \\
* *\end{array}$ & $\begin{array}{l}0.317 \\
* *\end{array}$ \\
\hline Global radiation & $\begin{array}{c}0.454 \\
* *\end{array}$ & $\begin{array}{c}0.406 \\
* *\end{array}$ & $\begin{array}{c}0.434 \\
* *\end{array}$ & $\begin{array}{c}0.386 \\
* *\end{array}$ & $\begin{array}{c}0.441 \\
* *\end{array}$ & $\begin{array}{c}0.381 \\
* *\end{array}$ & $\begin{array}{c}0.419 \\
* *\end{array}$ & $\begin{array}{c}0.453 \\
* *\end{array}$ \\
\hline
\end{tabular}

** significant on level $P=0.01$, * significant on level $P=0.05$

The performed Pearson's correlation test with the three investigated years' dry herb yield data did not show significant relationship with the nutrient settings $(r=0.155)$. In the preharvest period's first three weeks, neither the temperature nor the precipitation or the influence of the soil temperature is statistically evaluable. Precipitation has a negative medium effect from the sixth week before harvest. The soil temperature has a positive medium relationship from the fourth week preharvest. During the entire investigated period, we measured a positive medium relationship between the global radiation and the dry herb yield (Table 2).

Table 2

The relationship between the dry herb yield of the coneflower and the eight-week long preharvest period's meteorological characteristics (Debrecen, 2018)

\begin{tabular}{|c|c|c|c|c|c|c|c|c|}
\hline Dry yield & 1. week & 2. week & 3. week & 4. week & 5. week & 6. week & 7. week & 8. week \\
\hline Temperature & -0.131 & -0.130 & -0.036 & 0.008 & 0.022 & 0.039 & 0.091 & 0.122 \\
\hline Precipitation & -0.072 & -0.049 & $\begin{array}{c}-0.422 \\
* *\end{array}$ & $\begin{array}{c}-0.317 \\
* *\end{array}$ & $\begin{array}{c}-0.377 \\
* *\end{array}$ & $\begin{array}{c}-0.596 \\
* *\end{array}$ & $\begin{array}{c}-0.556 \\
* *\end{array}$ & $\begin{array}{c}-0.542 \\
* *\end{array}$ \\
\hline Air humidity & $\begin{array}{c}-0.608 \\
* *\end{array}$ & $\begin{array}{c}-0.580 \\
* *\end{array}$ & $\begin{array}{c}-0.590 \\
* *\end{array}$ & $\begin{array}{c}-0.551 \\
* *\end{array}$ & $\begin{array}{c}-0.571 \\
* *\end{array}$ & $\begin{array}{c}-0.499 \\
* *\end{array}$ & $\begin{array}{c}-0.574 \\
* *\end{array}$ & $\begin{array}{c}-0.611 \\
* *\end{array}$ \\
\hline Soil temperature & $\begin{array}{c}-0.292 \\
*\end{array}$ & -0.125 & 0.112 & $\begin{array}{c}0.320 \\
* *\end{array}$ & $\begin{array}{c}0.565 \\
* *\end{array}$ & $\begin{array}{c}0.556 \\
* *\end{array}$ & $\begin{array}{l}0.576 \\
* *\end{array}$ & $\begin{array}{c}0.542 \\
* *\end{array}$ \\
\hline Global radiaton & $\begin{array}{c}0.572 \\
* *\end{array}$ & $\begin{array}{c}0.434 \\
* *\end{array}$ & $\begin{array}{c}0.500 \\
* *\end{array}$ & $\begin{array}{c}0.394 \\
* *\end{array}$ & $\begin{array}{c}0.518 \\
* *\end{array}$ & $\begin{array}{c}0.384 \\
* *\end{array}$ & $\begin{array}{c}0.464 \\
* *\end{array}$ & $\begin{array}{c}0.570 \\
* *\end{array}$ \\
\hline
\end{tabular}

** significant on level $P=0.01$, * significant on level $P=0.05$

\section{CONCLUSIONS}

Every fertilization setting has less herb yield than the control group in 2016. In 2017 and 2018, with the increasing of the nutrient settings, the herb yield increased, too. In these two years, the maximum measured herb yield of the $\mathrm{N}_{75} \mathrm{P}_{100} \mathrm{~K}_{150}$ also exceeded the control setting's biggest yield in 2016 with $30 \%$. As for the roots' yield we observed fluctuation, but the biggest yield was observed in the case of the $\mathrm{N}_{75} \mathrm{P}_{100} \mathrm{~K}_{150}$ plots. Until now, we could not find an explanation for the initial fluctuation phenomena.

According to the Pearson's correlation test, in most cases, the air humidity and the precipitation has a negative medium effect on the raw and the dry herb yield. The raw and the dry herb yield has a positive relationship with the soil temperature and the global 
radiation. Temperature and the different nutrient settings do not have a significant effect on yield.

The regular annual nutrient supply has a positive effect on the Echinacea purpurea L. herb and root drug yield. However, taking into account the weather characteristics of the site, it may also significantly influence the amount of drug production.

\section{ACKNOWLEDGEMENT}

SUPPORTED BY THE ÚNKP-17-3. NEW NATIONAL EXCELLENCE PROGRAM OF THE MINISTRY OF HUMAN CAPACITIES"

\section{REFERENCES}

Babulka, P. (1998): A bíbor és a keskenylevelü kasvirág, Komplementer medicina, 2. évf., 12. szám, 48-49 pp.

Bernáth, J. (Szerk.) (2000): Gyógy- és aromanövények, Mezőgazda Kiadó, Budapest, http://dx.doi.org/10.1556/tarskut.27.2009.2.8

Capek, P.-Sutovská, M.-Kocmálová, M.-Franová, S.-Pawlaczyk, I.-Gancarz, R. (2015): Chemical and pharmacological profiles of the Echinacea complex, International Journal of Biological Macromolecules, 79. 388-391. https://doi.org/10.1016/j.ijbiomac.2015.05.010

Goodier, J. (2016): Medicinal Plants of North America, 2nd Edition, JIM MEUNINCK FALCON GUIDES, Guilford, Connecticut, Helena, Montana, 40-41 pp., https://doi.org/10.1108/rr-01-20170013

Meuninck, J. (2016): Medicinal Plants of North America, 2nd Edition, Falcon Guides, Guilford, Connecticut, Helena, Montana, 40-41 ptp.

Pluhár, Zs. (Szerk.) (2012): Korszerü gyógynövénytermesztési ismeretek, Budapesti Corvinus Egyetem, Kertészettudományi Kar, Gyógy- és aromanövények Tanszék

Praszna, L.-Lefler, J.-Lelik, L.-Vitányi, Gy. (1992): Termesztési kísérletek és hatóanyagvizsgálatok echinacea purpurea-val, Kertészet, Kertészeti és Élelmiszeripari Egyetem Kiadványai. A „Lippay János” tudományos ülésszak előadásai és poszterei, Gyógy- és Füszernövény termesztési szekció, 131-134 pp.
Raus, K.-Pleschka, S.-Klein, P.-Schoop, R.-Fisher, P. (2015): Effect of an Echinacea-Based Hot Drink Versus Oseltamivir in Influenza Treatment: A Randoized, Double-Blind, DoubleDummy, Multicenter, Noninferiority Clinical Trial, Current Therapeutic Research 77 (2015) 66-72. , https://doi.org/10.1016/j.curtheres.2015.04.001

Ross, I. A. (2001): Medicinal Plants of the World, Chemical Constituents, Traditional and Modern Medicinal Uses Volume 2, Springer Science+Business Media New York, https://doi.org/10.1007/978-1-59259-237-1

Sabra, A.-Daayf, F.-Remault, S. (2012): Differential physiological and biochemical responses os three Echinacea species to salamity stress, Scientia Horticulturae, vol. 135., 23-31., https://doi.org/10.1016/j.scienta.2011.11.024

Sutovská, M.-Capek, P.-Kazimierová, I.-Pappová, L.-Josková, M.Matulová, M.-Pawlaczyk, I.-Gancarz, R. (2015): Echinacea complex - chemical view and anti-asthmatic profile, Journal of Ethnopharmacology vol. 175., 163-171., https://doi.org/10.1016/j.jep.2015.09.007

Valkovszki, N. J.-Zámboriné Németh, É. (2011): Effects of growing conditions on content and composition of the essential oil of annual caraway (Carum carvi L. var. annua), Acta Alimentaria vol. 40 issue 2., 235-246., https://doi.org/10.1556/aalim.2010.0002 
